\title{
Evaluation of preventive measures for mother-to-child transmission of HIV in Aracaju, State of Sergipe, Brazil
}

\author{
Lígia Mara Dolce de Lemos ${ }^{[1]}$, Thaísa Fonseca Siqueira Rocha ${ }^{[2]}$, Marcos Vinícius da Conceição $0^{[2]}$, \\ Eduardo de Lemos Silva ${ }^{[3]}$, Alessandro Henrique da Silva Santos ${ }^{[4]}$ and Ricardo Queiroz Gurgel ${ }^{[5]}$
}

[1]. Departamento de Enfermagem, Universidade Federal de Sergipe, Aracaju, SE. [2]. Faculdade de Enfermagem, Universidade Federal de Sergipe, Aracaju, SE. [3]. Faculdade de Medicina, Faculdade Serra dos Órgãos, Teresópolis, RJ. [4]. Departamento de Estatística, Universidade Federal de Pernambuco, Recife, PE. [5]. Núcleo de Pós-Graduação em Medicina, Universidade Federal de Sergipe, Aracaju, SE.

\begin{abstract}
Introduction: The main route of human immunodeficiency virus (HIV) infection in children is from mother to child. The preventive measures established for the Aids Clinical Trial Group protocol 076 (ACTG 076) significantly reduces HIV vertical transmission rates. This study aims to evaluate the implementation of the ACTG 076 protocol in the maternity units of State of Sergipe, Brazilian northeast. Methods: This is a descriptive, retrospective study with a quantitative approach, with HIV positive women and children exposed, attending a Maternity reference for high-risk pregnancies. Data were obtained from patient records registered in the years 1994 to 2010. Results: Amongst the 110 pregnant women and exposed newborns, the ACTG 076 protocol was fully utilized in only $31.8 \%$ of the participants. During the prenatal period, zidovudine (ZDV) was taken by $79.1 \%$ of the pregnant women. Only $49.1 \%$ of HIV seropositive patients used ZDV during delivery. Two (1.8\%) children were considered infected and 50 (45.5\%) do not have a conclusive diagnosis to date. Conclusions: There were significant deficiencies in the prevention of mother-to-child transmission of HIV, including lack of compliance with the three phases of the ACTG 076 protocol; inadequacies in prenatal care; inappropriate mode of delivery and lack of adequate follow up of exposed children.
\end{abstract}

Keywords: HIV. Vertical transmission of infectious disease. Zidovudine. Post-exposure prophylaxis.

\section{INTRODUCTION}

The identification of the acquired immunodeficiency syndrome (AIDS) in 1981 was a major milestone in the history of mankind. Before its spread across the world, the human immunodeficiency virus (HIV) epidemic was initially restricted to a few cosmopolitan populations. Nowadays, the epidemiology of HIV infection is marked by the increasing occurrence in women, in smaller cities and poorer populations. The increased burden of HIV infection in women leads to substantial increases in children ${ }^{1,2}$.

The mother-to-child transmission (MTCT) of HIV, also called vertical transmission, may occur at various moments: during pregnancy, during labor and delivery or after birth through breast feeding ${ }^{3}$. The risk of transmission may range between $30 \%$ and $35 \%$ during pregnancy, from $60 \%$ to $65 \%$ during the immediate prenatal period and during labor itself $f^{4,5}$. There is an additional of risk between $7 \%$ and $22 \%$ if the child is breastfed by the mother ${ }^{6,7}$.

In order to minimize this problem protocols and prophylactic regimes have been established. In 1994 the Aids Clinical Trial Group (PACTG) 076 Protocol was published detailing the effective use of drug therapy to reduce MTCT. The protocol included the oral administration of the antiretroviral zidovudine (ZDV) during pregnancy and for the newborn, and intravenous use during delivery. The result of this study demonstrated that the use of ZDV reduced vertical transmission by $67.5 \%{ }^{8}$.

Address to: Profa Lígia Mara Dolce de Lemos. Av. Adélia Franco 2288/702, Condomínio Costa Dourada, Ed. Salinas, Bairro Luzia, 49048-010 Aracaju, SE, Brasil.

Phone: 5579 3246-6893

e-mail: ligiadolce@gmail.com

Received in 26/01/2012

Accepted in 08/05/2012
In Brazil, a 2002 study by Connor et al. ${ }^{8}$ was the basis of the implementation of Projeto Nascer ${ }^{9}$. This project aims to train all health care providers in maternity hospitals to reorganize services in order to improve the quality of care for pregnant and puerperal women and their newborns. It also intends to reduce vertical transmission of HIV and to control congenital syphilis. According to the Ministerial Protocol of Brazil, all patients have free access to antiretroviral (ARV) drugs as clinically indicated, HIV testing during pregnancy and monitoring of viral load and cluster of differentiation (CD4) count ${ }^{3,9}$.

Aracaju, the capital City of Sergipe, has the highest rate of HIV/ AIDS in the state. The first adult female case was diagnosed in 1990, and the first case of vertical transmission in $1993^{10}$. The increasing number of HIV infected children makes the situation alarming, as evidenced by a study conducted at the public maternity hospitals in Sergipe (Sistema Único de Saúde - SUS) where a HIV seroprevalence of $0.42 \%$ was detected among pregnant women ${ }^{11}$.

The benefits of HIV vertical transmission prophylaxis are well known but there are often failures regarding the implementation of the recommended protocols for prevention of MTCT. This study aims to evaluate the use of the ACTG 076 protocol in pregnant women and children exposed to HIV at the main reference maternity hospital in the city of Aracaju from 1994 to 2010.

\section{METHODS}

This is a descriptive, retrospective study with a quantitative approach. We included HIV positive mothers and their exposed children, admitted to Nossa Senhora de Lourdes Maternity Hospital (MNSL) from July 1994 to April 2010. This institution was selected because it is the referral hospital for all high risk pregnancies in Sergipe treating the majority of HIV positive pregnant women in the State. The data collection began in July 2010 and ended in April 2011. 
During the studied period 158 HIV seropositive women were admitted in the reference maternity. A significant number of 110 pregnant women and their exposed children was included. The 48 missing patients were not included because their records were missed when the maternity changed to the new building in 2006 . To estimate the significance of the sample ${ }^{12}$ we estimated a $50 \%$ compliance of the ACTG 076 protocol, with a maximum error of $7 \%$ and a $95 \%$ Confidence Interval additional $20 \%$ patients accounting for patients records not found.

All cases of HIV seropositive pregnant women and their exposed children were identified from the Information System for Reportable Diseases (SINAN). Other sources of information were used to complement the database, namely the State Health Department and outpatient medical records from the sexually transmitted disease/human immunodeficiency virus/acquired immunodeficiency syndrome (STD/HIV/AIDS) service at the University Hospital (HU).

All information was collected on a standard form and then entered into database. The variables for analysis included maternal sociodemographic factors, details of prenatal care and labor and the current status of the child. Residence of individuals was categorized as Aracaju Metropolitan Area (which includes Aracaju (capital), Barra dos Coqueiros, Nossa Senhora do Socorro and São Cristóvão) or other municipalities of Sergipe.

Regarding the use of the ACTG 076 protocol, the three phases were separately analyzed. Each step recommended by the protocol included one or more interventions. Phase 1 consisted of the use of ARV during pregnancy; phase 2 was the use of intravenous ZDV during labor and the mode of delivery according viral load result, and phase 3 consisted of treatment with oral ZDV for the child and avoidance of breastfeeding ${ }^{8}$.

Data analysis was performed using SPSS version 13. A descriptive analysis of the categorical variables produced simple absolute frequencies and percentage. To compare differences and distribution between proportions the chi-square test $(x 2)$ was used. To evaluate the influence of prenatal care on the implementation of the ACTG 076 protocol was used Fisher's exact test. The significance value was established as $5 \%(p<0.05)$.

\section{Ethical considerations}

All ethical principles of Brazilian research (Resolution 196/96) were upheld. There was no direct patient contact; therefore it was not necessary to obtain individual consent. This study was approved by the Ethics and Research Committee of Federal University of Sergipe on $1^{\text {st }}$ April 2011, registered number 0183.0.107.000-10.

\section{RESULTS}

From 1994 to 2010, there were 158 HIV positive mothers registered at Nossa Senhora de Lourdes Maternity Hospital and 110 of these were included in the survey. Maternal age ranged between 17 and 45 years with a predominance of the age group 26 to 35 years (60.9\%). There were $64(58.2 \%)$ women living in the metropolitan area of Aracaju. Over half (58.2\%) had less than seven years of formal education. Regarding employment status, 17 (15.5\%) were employed or self-employed, 15 (13.6\%) were unemployed and 38 (34.5\%) were housewives and/or students. The majority $(68.2 \%)$ of participants
TABLE 1 - Distribution of sociodemographic characteristics and acquisition factors for HIV seropositive pregnant women in MNSL, State of Sergipe, Brazil, 1994 to 2010.

\begin{tabular}{|c|c|c|c|c|}
\hline Variable & Number & Percentage & $x^{2}$ & $\overline{p \text {-value }}{ }^{a}$ \\
\hline \multicolumn{5}{|l|}{ Age (years) } \\
\hline 17 to 25 & 17 & 15.5 & 38.74 & $<0.0001$ \\
\hline 26 to 35 & 67 & 60.9 & & \\
\hline 36 to 45 & 26 & 23.6 & & \\
\hline \multicolumn{5}{|l|}{ Residence } \\
\hline Aracaju Metropolitan area & 64 & 58.2 & 56.96 & $<0.0001$ \\
\hline other municipalities of Sergipe & 45 & 40.9 & & \\
\hline unknown & 1 & 0.9 & & \\
\hline \multicolumn{5}{|l|}{ Years of education } \\
\hline 0 to 7 years & 64 & 58.2 & 36.01 & $<0.0001$ \\
\hline$>7$ years & 33 & 30.0 & & \\
\hline unknown & 13 & 11.8 & & \\
\hline \multicolumn{5}{|l|}{ Professional situation } \\
\hline employed/self-employed & 17 & 15.5 & 19.38 & 0.0002 \\
\hline unemployed & 15 & 13.6 & & \\
\hline housewives/students & 38 & 34.5 & & \\
\hline unknown & 40 & 36.4 & & \\
\hline
\end{tabular}

\begin{tabular}{lrrrr}
\hline Sexual partnership & 75 & 68.2 & 172.0 & $<0.0001$ \\
steady partners & 3 & 2.7 & & \\
casual partners & 5 & 4.5 & & \\
steady and casual partners & 4 & 3.6 & & \\
others & 23 & 20.9 & & \\
unknown & & & & \\
\hline HIV exposure category & 14 & 12.7 & 123.38 & $<0.0001$ \\
$\quad$ current partner with HIV & 17 & 15.5 & & \\
former partner with HIV & 2 & 1.8 & & \\
intravenous drug users & 77 & 70.0 & & \\
$\quad$ unknown & & & & \\
\hline Period of diagnosis of HIV infection & 53 & 48.2 & 97.72 & $<0.0001$ \\
$\quad$ before pregnancy & 40 & 36.4 & & \\
during pregnancy & 12 & 10.9 & & \\
during delivery & 1 & 0.9 & & \\
after delivery & 4 & 3.6 & & \\
unknown & & & \\
\hline
\end{tabular}

HIV: human immunodeficiency virus; MNSL: Nossa Senhora de Lourdes Maternity Hospital. $\chi^{2}$ : chi-square calculated; ${ }^{a}$-value of chi-square.

were in a long-term relationship with a steady partner. The diagnosis of HIV infection had been made before the prenatal period in $53(48.2 \%)$ cases, during the current pregnancy in 40 (36.4\%), at birth in $12(10.9 \%)$ and 1 (0.9\%) woman was diagnosed after delivery (Table 1).

Concerning prenatal services, $91.8 \%$ of patients attended prenatal appointments, but only $44.5 \%$ (49) had less than 6 visits. The results for HIV and syphilis (VDRL - Venereal Disease Research Laboratory) in the prenatal period was positive in $53(48.2 \%)$ and 11 (10\%) cases, respectively. It was noted that $79.1 \%$ of the pregnant women were on ARV therapy in the prenatal period (Table 2).

Regarding the ACTG 076 protocol, 87 (79.1\%) women were taking oral ZDV during pregnancy (phase 1), 54 (49.1\%) received intravenous ZDV during delivery, and had a cesarean section if their viral load exceeded 1,000 copies/ml (phase 2). Furthermore, 77 (70\%) children received the oral ZDV and were not breastfed (phase 3). Although phases 1 and 3 had high rates of compliance individually, the number 
of women who received all three phases of the protocol was only 35 (31.8\%) (Table 3).

TABLE 2 - Prenatal care for HIV seropositive pregnant women in Nossa Senhora de Lourdes Maternity Hospital, State of Sergipe, Brazil, 1994 to 2010.

\begin{tabular}{|c|c|c|c|c|}
\hline Variable & Number & Percentage & $x^{2}$ & p-value ${ }^{a}$ \\
\hline \multicolumn{5}{|l|}{ Had prenatal care } \\
\hline yes & 101 & 91.8 & 169.32 & $<0.0001$ \\
\hline no & 4 & 3.6 & & \\
\hline unknown & 5 & 4.5 & & \\
\hline \multicolumn{5}{|l|}{ Number of visits } \\
\hline$<6$ & 49 & 44.5 & 43.52 & $<0.0001$ \\
\hline$\geq 6$ & 38 & 34.5 & & \\
\hline no prenatal care & 4 & 3.6 & & \\
\hline unknown & 19 & 17.3 & & \\
\hline \multicolumn{5}{|l|}{ HIV test } \\
\hline positive & 53 & 48.2 & 60.54 & $<0.0001$ \\
\hline not tested & 14 & 12.8 & & \\
\hline HIV positive before prenatal care & 41 & 37.3 & & \\
\hline unknown & 2 & 1.7 & & \\
\hline \multicolumn{5}{|l|}{ Use of ARV during pregnancy } \\
\hline yes & 87 & 79.1 & 106.70 & $<0.0001$ \\
\hline no & 19 & 17.3 & & \\
\hline unknown & 4 & 3.6 & & \\
\hline \multicolumn{5}{|l|}{ Syphilis test } \\
\hline positive & 11 & 10.0 & 73.49 & $<0.0001$ \\
\hline negative & 66 & 60.0 & & \\
\hline not tested & 13 & 11.8 & & \\
\hline unknown & 20 & 18.2 & & \\
\hline
\end{tabular}

HIV: human immunodeficiency virus; ARV: antiretroviral; $\chi^{2}$ : chi-square calculate. ${ }^{a} p$-value of chi-square.

TABLE 3 - ACTG 076 protocol use in HIV positive pregnant women and exposed children in Nossa Senhora de Lourdes Maternity Hospital, State of Sergipe, Brazil, 1994 to 2010.

\begin{tabular}{lcccc}
\hline Phases of ACTG 076 protocol & Number & Percentage & $\chi^{2}$ & p-value $^{\mathbf{a}}$ \\
\hline Phase 1: during pregnancy & 87 & 79.1 & 106.70 & $<0.0001$ \\
$\quad$ yes & 19 & 17.3 & & \\
no & 4 & 3.6 & & \\
$\quad$ ignored & & & & \\
\hline Phase 2: delivery & 54 & 49.1 & 49.16 & $<0.0001$ \\
yes & 54 & 49.1 & & \\
no & 1 & 0.9 & & \\
does not apply & 1 & 0.9 & & \\
ignored & & & & \\
\hline
\end{tabular}

\section{Phase 3: after delivery}

$\begin{array}{lrrr}\text { yes } & 77 & 70.0 & 124.10<0.0001 \\ \text { no } & 19 & 17.3 & \\ \text { does not apply (stillbirth) } & 2 & 1.8 & \\ \text { unknown } & 12 & 10.9\end{array}$

\section{General: three complete phases}

\begin{tabular}{lrrr} 
yes & 35 & 31.8 & $90.65<0.0001$ \\
no & 65 & 59.1 & \\
do not apply (stillbirth) & 2 & 1.8 \\
unknown & 8 & 7.3 \\
\hline
\end{tabular}

ACTG 076: Aids clinical trial group 076; $\chi^{2}$ : chi-square; ${ }^{a}$-value of chi-square.
Of the 101 pregnant women who were attended during the prenatal, 84 (84.8\%) received a phase 1 protocol; 52 (52.5\%) received the protocol in phase 2 and $72(80.9 \%)$ completed phase 3 . Of the women who did not attend prenatal care, none completed the protocol in Phase 1 and Phase 2. Only in Phase 3 there were 2 (50\%) women who did not attend prenatal care but completed the protocol.-However, when evaluating prenatal care influence on the implementation of the protocol, only individuals at the first phase were influenced by prenatal care attendance (Fisher's exact test: $p=0.027$ ) (Table 4).

From 40 women HIV positive before prenatal care attendance, 39 (97.5\%) received ARV during pregnancy, and also 46 of 51 with HIV positive during pregnancy received ARV during prenatal care.

During follow up two (1.8\%) children were found to be infected with HIV and 56 (50.9\%) were confirmed HIV negative, 11 (10\%) were lost to follow-up at the clinic and 39 (35.5\%) are still being monitored. It is worth mentioning that in one case, the child deemed HIV negative was not old enough to have a definitive diagnosis made.

TABLE 4 - ACTG 076 protocol application in HIV positive pregnant women and exposed children according to prenatal care use in MNSL, State of Sergipe, Brazil, 1994 to 2010.

\begin{tabular}{|c|c|c|c|c|c|c|c|c|}
\hline \multirow[b]{3}{*}{ Prenatal } & \multicolumn{8}{|c|}{ ACTG 076 Protocol } \\
\hline & \multicolumn{2}{|c|}{ Phase $1^{a}$} & \multicolumn{2}{|c|}{ Phase $2^{b}$} & \multicolumn{2}{|c|}{ Phase $3^{C}$} & \multicolumn{2}{|c|}{ Complete protocolo } \\
\hline & yes & no & yes & no & yes & no & yes & no \\
\hline yes & 84 & 15 & 52 & 47 & 72 & 17 & 34 & 59 \\
\hline no & 0 & 2 & 0 & 2 & 2 & 2 & 0 & 4 \\
\hline$p$-value $e^{e}$ & \multicolumn{2}{|c|}{0.027} & \multicolumn{2}{|c|}{0.057} & \multicolumn{2}{|c|}{0.184} & \multicolumn{2}{|c|}{0.294} \\
\hline
\end{tabular}

ACTG 076: Aids clinical trial group 076; HIV: human immunodeficiency virus; MNSL: Nossa Senhora de Lourdes Maternity Hospital; ${ }^{a}$ Use of antiretroviral during pregnancy: unknown 9 cases; ${ }^{b}$ Use of intravenous zidovudine during delivery, value of the viral load and type of delivery: unknown 7 cases; 'Use of zidovudine syrup in children and no breastfeeding by the mother or crossed from other mother: unknown 17 cases; ${ }^{d}$ Complete protocol: unknown 13 cases; ${ } e_{p}$-value of Fisher's exact test.

\section{DISCUSSION}

It is known that one of the most effective strategies to reduce vertical transmission of HIV is to reduce the maternal viral load during pregnancy. It is considered that not receiving ZDV during prenatal care, at childbirth and in immediate postnatal period are major factors in the failure to control perinatal HIV transmission ${ }^{13,14}$. The evaluation of preventive interventions during maternity care is important to ascertain if the recommended protocol is being effectively implemented ${ }^{14}$. Knowledge of the patients' sociodemographic characteristics enables more targeted interventions for the population at risk ${ }^{15}$.

The predominant maternal age was found to be at the most fertile ages, thereby increasing the probability of future pregnancy and potential HIV transmission. The sociodemographic profile was similar to that found in other studies ${ }^{16,17}$, in which patients with lower education levels may have reduced quality of prenatal care. If there was prior knowledge of HIV positivity, there was a more effective reduction in vertical transmission ${ }^{18}$. In $10.9 \%$ of pregnant women, the diagnosis occurred during delivery, meaning a missed opportunity for preventive intervention during the prenatal period.

The quality of prenatal care could not be fully evaluated, because we did not know the date of onset or when actions were implemented during visits. In a previous study in Sergipe, $42.1 \%$ of pregnant women attended fewer than six consultations ${ }^{11}$, a similar rate to that found in this survey (44.5\%). This inadequate attendance led to inadequate 
testing for HIV (12.8\%) and syphilis (11.8\%), demonstrating poor quality prenatal care ${ }^{18}$.

At first glance, with the exception of phase 2, the use of the ACTG 076 protocol appears to be in accordance with established standards, as most pregnant women and newborns completed phases 1 and 3. However, when analyzing all phases together, the high levels of coverage drop considerably. Lower figures are found in the study by Silva et al. ${ }^{19}$, where only $1.5 \%$ of pregnant women and newborns received complete prophylaxis as per recommendations. The lower uptake of phase 2 (at birth) when compared to the other studies, is worrying because it is precisely at this stage, where obstetric factors are critical, that most virus transmission occurs ${ }^{20}$. It is worth noting that this intervention during this period does not depend on the pregnant woman, but on the health care staff working at the maternity hospital. The only exception is in cases where the patients should have disclosed their known HIV status when presenting in labor but did not.

A previous retrospective study ${ }^{17}$ reported that the rate of vertical transmission of HIV was $6.6 \%$ in pregnant women who received the complete ACTG076 protocol and 34\% for those who received no intervention. This corroborates the effectiveness of the prophylactic measures proposed by Connor ${ }^{8}$.

In the present study, the evidence of the relationship between prenatal attendance and the use of prophylactic ZDV demonstrates that primary care is a significant factor in implementing prophylactic measures. Prenatal visits provide HIV testing and ensure the involvement of HIV seropositive pregnant women in their care.

More than $90 \%$ of seropositive patients used ARV, demonstrating that the weaknesses of the system are starting to be overcome. The fact that most pregnant women are already aware of their status before pregnancy influences their adherence to the protocol measures. A lower percentage was found in a study of Lana and Lima ${ }^{21}$, where the rate was $44.8 \%$. With respect to the onset of prophylaxis in children, some neonates did not receive oral ZDV for the first $2 \mathrm{~h}$ after delivery (data not shown). These neonates received the medication during the first $24 \mathrm{~h}$, but not during the first two, when it is most effective. This demonstrates the importance of knowing the status of the mother as early as possible to enable timely intervention for the child.

Failures to implement protocol measures increase the chance for mother to child transmission of HIV. A European study revealed that cesarean section is the most effective clinical procedure, even in patients with undetectable viral load, with $90 \%$ reduction in the risk of vertical transmission ${ }^{20}$.

Another study showed that after implementation of the protocol, $77.1 \%$ of the children exposed to HIV were not infected ${ }^{22}$. The numbers of HIV negative children in this study could be higher if all steps of the protocol were completed. It is noteworthy that many exposed children still do not have a final diagnosis, which could represent changes in the proportions observed. This problem was present in another study, which showed that $20 \%$ of mothers did not know the HIV status of their children up to eight months after delivery ${ }^{23}$.

One of the limitations of this research was the existence of a number of non-registered patients combined with contradictory information found in some records, particularly pertaining to the risk of disease enhancement in the mother during pregnancy, duration of prophylaxis with ZDV in pregnancy and date of onset of prenatal care. This missing information made a more detailed and accurate characterization of the current status of MTCT in State of Sergipe impossible.

This study aimed to evaluate the actual situation in interventions to reduce mother to child transmission of HIV. The findings will contribute to improvement in prenatal services at the main reference maternity unit of Sergipe.

Despite the weaknesses found, many interventions do not depend on a single service, thus it is necessary to work with other sectors such as health system managers, with special attention to quality improvement for prenatal services, professional training and increased population awareness for the prevention of HIV vertical transmission.

Among the 110 pregnant women and newborns here studied, the full ACTG 076 protocol was carried out in only $31.8 \%$ of cases. A similar problem was found in another study of the ACTG protocol which demonstrated that only 4 (4.5\%) HIV-positive mothers and their exposed children received full or partial interventions as per the recommended protocol ${ }^{19}$.

There were two (1.8\%) confirmed cases of HIV in children, which reveal important shortcomings to be examined, considering that Nossa Senhora de Lourdes maternity hospital is the reference unit for Sergipe. It is important to note that the pregnant women in this study were socioeconomically vulnerable with a relatively low level of education. These factors may have limited the full implementation of preventive measures as recommended by the protocol.

The findings of this study reveal significant shortcomings in the prevention of MTC transmission, including the lack of implementation of the three phases of the ACTG 076 protocol, deficiencies in prenatal care, inadequate modes of delivery and lack of follow-up care for the child.

Although the study population did not cover the entire state, it is worthwhile to bear in mind that the studied maternity unit is the reference centre for all high risk pregnancies in Sergipe, representing the overall state situation. However it is necessary to conduct studies in other hospitals to improve overall generalizability.

\section{ACKNOWLEDGMENTS}

To the employees of the Coordination for Sexually Transmitted Disease/Acquired Immunodeficiency Syndrome (STD/AIDS) of Sergipe, Center of Medical Specialties Aracaju Siqueira Campos (CEMAR) and the Maternity Hospital Nossa Senhora de Lourdes (MNSL). We thank DrChinenye llozue for the English revision of this manuscript and Vitor Santana Santos for the statistics revision.

\section{CONFLICT OF INTEREST}

The authors declare that there is no conflict of interest.

\section{FINANCIAL SUPPORT}

Own resources of the researchers. 


\section{ABSTRACT IN PORTUGUESE}

\section{Avaliação das ações de prevenção da transmissão materno-infantil do HIV em Aracaju, Estado de Sergipe, Brasil}

Introdução: A principal forma de infecção do vírus da imunodeficiência humana (HIV) em crianças é pela transmissão materno-infantil. As ações profiláticas estabelecidas pelo protocolo Aids Clinical Trial Group 076 (ACTG 076), reduziram significativamente as taxas de transmissão vertical do HIV. Este estudo objetivou avaliar a aplicação do protocolo ACTG 076 na maternidade de referência no Estado de Sergipe, nordeste brasileiro. Métodos: Trata-se de um estudo descritivo, retrospectivo com abordagem quantitativa, com mulheres HIV soropositivas e crianças expostas atendidas em uma maternidade para gestações de alto risco. Os dados foram obtidos dos registros de pacientes registrados nos anos de 1994 a 2010. Resultados: Entre as 110 gestantes e recém-nascidos expostos, o uso completo do protocolo ACTG 076 foi utilizado em apenas $31,8 \%$ dos participantes. No pré-natal, a zidovudina (ZDV) foi utilizada em $79,1 \%$ das gestantes. $O$ uso da ZDV durante o trabalho de parto ocorreu em $49,1 \%$ das gestantes HIV reagentes. Duas (1,8\%) crianças foram consideradas infectadas e 50 (45,5\%) ainda não têm diagnóstico definido. Conclusões: Foram detectadas falhas significativas na prevenção da transmissão materno-infantil, dentre as quais, a falta do cumprimento das três fases do protocolo ACTG 076: carências no pré-natal, tipo de parto inadequado e perdas de seguimento para acompanhamento da criança exposta.

Palavras-chaves: HIV. Transmissão vertical de doenças infecciosas. Zidovudina. Profilaxia pós-exposição

\section{REFERENCES}

1. Brito AM, Castilho EA, Szwarcwald CL. Aids e infecção pelo HIV no Brasil: uma epidemia multifacetada. Rev Soc Bras Med Trop 2000; 34:207-217.

2. Fonseca MGP, Bastos FI. Twenty-five years of the AIDS epidemic in Brazil: principal epidemiological findings, 1980-2005. Cad Saude Publica 2007; 23:333-344.

3. Ministério da Saúde. Coordenação Nacional de DST/Aids. Recomendações para profilaxia da transmissão vertical do HIV e terapia antirretroviral em gestantes. Brasília: Ministério da Saúde; 2010.

4. European Collaborative Study. Caesarean section and the risk of vertical transmission of HIV-1 infection. Lancet 1994; 343:1464-1467.

5. Garcia PM, Kalish LA, Pitt J, Minkoff H, Quinn TC, Burchett SK, et al. Maternal levels of plasma human immunodeficiency virus type 1 RNA and the risk of perinatal transmission: women and infants transmission study group. N Engl J Med 1999; 341:394-402.

6. Mofenson LM. Mother-child HIV-1 transmission: timing and determinants. Obstet Gynecol Clin North Am 1997; 24:759-784.

7. Dunn DT, Newell ML, Ades AE, Peckham CS. Risk of human immunodeficiency virus type-1 transmission through breastfeeding. Lancet 1992; 340:585-588.
8. Connor EM, Sperling RS, Gelber R, Kiselev P, Scott G, O'Sullivan MJ, et al. Reduction of maternal-infant transmission of human immunodeficiency virus type 1 with zidovudine treatment. Pediatric AIDS Clinical Trials Group Protocol 076 Study Group. N Engl J Med 1994; 331:1173-1180.

9. Ministério da Saúde. Coordenação Nacional de DST/Aids. Projeto Nascer. Brasília: Ministério da Saúde; 2003.

10. Secretaria Estadual de Saúde de Sergipe (SES). Coordenação Estadual de DST/AIDS. Boletim Epidemiológico dos casos de Aids em Sergipe até dezembro de 2003. Aracaju: SES; 2004.

11. Lemos LMD, Gurgel RQ, Fabbro ALD. Prevalência do vírus HIV em Parturientes de maternidades vinculadas ao SUS. Rev Bras Ginecol Obste 2005; 27:32-36.

12. Bolfarine $H$, Bussad W. Elementos de amostragem. São Paulo: Editora Blucher; 2005.

13. Succi RCM. Grupo de Estudo da Sociedade de Pediatria para avaliar a transmissão Materno-Infantil do HIv. Mother-to-child transmission of HIV in Brazil during the years 2000 and 2001: results of a multi-centric study. Cad Saude Publica 2007; 23 (supl V):379-389.

14. Brito AM, Sousa JL, Luna CF, Dourado I. Tendência da transmissão vertical de AIDS após terapia anti-retroviral no Brasil. Rev Saude Publica 2006; 40 (supl):18-22.

15. Neves CAS, Gir E. HIV positive mothers' Beliefs about mother-to-child Transmission. Rev Latino-am Enf 2006; 14:781-788.

16. Turchi MD, Duarte LS, Martelli CMT. Mother-to-child transmission of HIV: risk factors and missed opportunities for prevention among pregnant women attending health services in Goiânia, Goiás State, Brasil. Cad Saude Publica 2007; 23:390-401.

17. Amaral E, Asssis-Gomes F, Milanez H, Cecatti JG, Vilela MM, Silva JLP. Implementação oportuna de intervenções para reduzir a transmissão vertical do HIV: uma experiência bem sucedida. Rev Panam Salud Publica 2007; 21:357-364.

18. Cavalcante MS, Silveira ACB, Ribeiro AMS, Ramos Júnior AN Prevenção da transmissão vertical do vírus da imunodeficiência humana: análise da adesão às medidas de profilaxia em uma maternidade de referência em Fortaleza, Ceará, Brasil. Rev Bras Saude Matern Infant 2008; 8:473-479.

19. Silva MJM, Mendes WDS, Gama MEA, Chein MBC, Veras DS. Perfil clínicolaboratorial de crianças vivendo com HIV/AIDS por transmissão vertical em uma cidade do Nordeste brasileiro. Rev Soc Bras Med Trop 2010; 43:32-35.

20. Thorne C, Patel D, Fiore S, Peckham C, Newell ML, European Collaborative Study. Mother-to-child transmission of HIV infection in the era of highly active antiretroviral therapy. Clin Infec Dis 2005; 40:458-465.

21. Lana FCF, Lima AS. Avaliação da prevenção da transmissão vertical do HIV em Belo Horizonte, MG, Brasil. Rev Bras Enferm 2010; 63:587-594.

22. Torres SR, Luz AMH. Gestante HIV+ e crianças expostas: estudo epidemiológico da notificação compulsória. Rev Gaucha Enferm Porto Alegre 2007; 28:505-511.

23. Gonçalves VLMA, Troiani C, Ribeiro AA, Spir PRN, Gushiken K, Vieira RB, et al. Vertical transmission of HIV-1 in the western region of the State of São Paulo. Rev Soc Bras Med Trop 2011; 44:4-7. 